\title{
Review on: Advances of Research on Wind Erosion and Wind Erosivity in Sudan
}

\author{
motasim abdelwahab ${ }^{1}$ and mukhtar mustafa ${ }^{2}$ \\ ${ }^{1}$ Omdurman Islamic University \\ ${ }^{2}$ University of Khartoum
}

July 7,2020

\begin{abstract}
Wind erosion process is natural process but might be substantially accelerated by adverse human activities. Wind erosion in the arid and semiarid zones, in particular, it may have dramatic impact on the current and potential productive capacity of the lands. The main goal of this paper is to present review of research on wind erosion which is prevalent in Sudan, besides displaying studies and research that must be carried out to fill the gaps in wind erosion research. Due to limited financial resources for anti-desertification research, there is a real gap in combating desertification research generally and wind erosion especially such as: stabilizing soil particles by various natural or synthetic cementing and flocculating materials that increase the non- erodiable soil particles on the soil surface, maintaining sufficient vegetative cover and establishing barriers or shelter belts barriers to reduce effective field length traveled by the wind. Lack of studies for measures sand encroaching into the Nile, winds data analysis beside calculation of wind erosivity, losses of nutrients and organic matter particularly that caused by wind erosion. Still there is urgent need to conduct researches on design and implementation of shelter belts and specify type of trees, number of rows, density and distance. Moreover intensity wind erosion research conducted in a part of affected states. It is time to fill the gap in studies and research and covers the all types of desertification processes integrated with sustainable development program, poverty alleviation and national action programmer for combating desertification.
\end{abstract}

\section{Introduction}

In the Earth Summit desertification was defined as: "Land degradation in arid, semi-arid and dry sub-humid areas resulting from various factors including climatic variations and human activities", and it was envisaged that desertification should be combated through a national action program integrated with sustainable development program at the local level (Lean,1995). The accepted desertification processes include degradation of vegetative cover, wind erosion, water erosion, salinization and sodication, reduction of organic matter, soil crusting and compaction, accumulation of substances, which are toxic to plants and animals in soils. The first four processes are considered determinative because they are widely spread and have greater adverse impact than the remaining three, which are considered subordinate. The definition depicts two main causes of desertification, namely climatic variation and adverse human activities (Lookwood, 1988; Hatfield, 1990; Nicholls, 1991; and Hodgkinson, 1992). The latter cause exacerbates the relatively slow rate of desertification caused by the natural climatic variation. Arid, semi-arid, and dry sub-humid areas, together with hyper-arid areas, constitute drylands (UNEP, 1994), home to about 3 billion people (van der Esch et al., 2017). The geographic classification of drylands is often based on the aridity index (AI) (Koutroulis, 2019; Prăvălie, 2016)

In central Sudan, the drought periods of 1968 and 1972 were preceded by above average rainfalls (floods) in many parts of the region. In 1962 Lake Chad recorded its highest level in the $20^{\text {th }}$ century and the widespread flooding drove many people from their villages. In contrast the drought conditions after 1965 reduced the 
Lake's level so low that irrigation was stopped during 1984-1986 (Kolawole, 1987; 1988). Periods of prolonged droughts like the great Sahelian drought (1968-1973) may occur. High aridity is an adverse climatic condition that creates fragile ecosystems, which can easily be upset by adverse human activities.

\subsection{Study area}

The study area was Sudan $\left(1,882,000 \mathrm{Km}^{2}\right)$. It is a northeast African country at latitudes 14 and $22^{\circ}$ north and longitudes $22^{\circ}$ and $38^{\circ}$ east. Increasing temperature as a result of greenhouse effect (global warming) is an important factor in climate change. Sudan is getting warmer. A change of $0.5-3^{\circ} \mathrm{C}$ temperature was recorded (Taha et al., 2013). Vegetation biomass is seriously affected by this change. There is a high variation in spatial and temporal distribution of rainfall in Sudan. Lines of equal rain fall depth (isohyets) were used by (Harison and Jakson, 1958) to classify the vegetation zone of Sudan. Sudan is dominated by two types of winds, the dry north easterly wind in winter (October, November, December, January and February) and the humid southerly wind in rainy season during (may, June, July, august and September). Aridity index (AI) is defined as a measurement of precipitation divided by evapotranspiration. Five degrees of aridity were defined (0.03 - 0.65) by (Dregne et al., 1991) in and become global measure.

\subsection{Desertification causes}

\subsubsection{Desertification and human being role in Sudan}

After independent in 1956 Sudan population enumerated was 10.1 million. Population increased to 14.8 million in 1973. In 1983 census 19.6 million was reported. Population densities was about 11 person $/ \mathrm{km}^{2}$ .This density increased to 22 person $/ \mathrm{km}^{2}$ as the population doubled from 19.6 million in 1983 to (38) million in 2014 (National Censes Report, 2010). Density will be 50person $/ \mathrm{km}^{2}$ by year 2050 . To feed this huge population Sudan will import everything considering (prediction of $5-25 \%$ crops losses by 2050) otherwise the ghost of famine will exist as output due to decrease in yield productivity and increase population. Eight million people northern and southern Sudan faced moderate to high levels food insecurity in 2010 (FEWSENT, 2011).

People can be a major asset in reversing a trend towards degradation. However, they need to be healthy and politically and economically motivated to care for the land, as subsistence agriculture, poverty, and illiteracy can be important causes of land and environmental degradation (Beinroth et al., 1994 and Lal, 1994).

In the arid and semi-arid zones in developing countries, e.g. Sudan, the relatively poor population in the rural areas seeks sustenance from the natural resources of their fragile ecosystems. They misuse the land through over and irrational cultivation of marginal lands, overgrazing, wood cutting and deforestation, uprooting of shrubs, burning of grasslands, forests and shrubs, and lowering of the ground water due to excessive water use. These activities cause degradation of the land, which is steadily accelerated due to the exponential increase in human and livestock pressures. These inevitable adverse activities prompted by the poverty of the local communities accentuate desertification, more poverty, and more reliance on the fragile ecosystems; thus completing a poverty vicious circle. The use of heavy machinery in mechanized farming may lead to compaction, which increases soil strength, limit root development, and proliferation, and thereby reduce plant growth and crop yield (Ayoub, 1998, 1999; Izzeldin et. al., 2000).

\subsubsection{Desertification and climate change}

Recently, climate change is recognized as a factor that enhances desertification (Mustafa, 2007). In developed countries industrial activities prompting the excessive use of fossil fuel coal is an adverse human activity that contributes heavily to climate change.

Climate change is mainly due to the increase of green house gases (GHGs), which include carbon dioxide, methane, troposphere ozone, nitrous oxide and chlorofluorocarbons (CFCs). These gases prevent the escape of heat into space, a phenomenon known as green house effect. The principal green house gas is carbon dioxide, which is emitted by power plants, automobiles, and other sources. Furthermore, vegetation degradation, e.g. deforestation, and overgrazing of rangelands reduces $\mathrm{CO}_{2}$ photosynthetic entrapment. The temperature 
of the planet is governed by the energy balance between the incoming solar energy absorbed by the earthatmosphere system and the infrared energy emitted back by that system. If there are no GHGs, the planetary temperature will be $-20^{\circ} \mathrm{C}$. However, the global average temperature is $15^{\circ} \mathrm{C}$. This was explained by the fact that these GHGs in the atmosphere absorb and re-emit downward the back infrared radiation that would have otherwise escaped more immediately into space. Climate change is a matter of fact. The ten hottest years on record have occurred since 1990, including 2005, which is the warmest year on record (IPCC, 2001a). Global warming is an international phenomenon caused predominantly by industrial countries and endured by developing countries. Developed countries contribute heavily to climate change through industrial activities that emit excessive amounts of GHGs.

Desertification is a major constraint of the development of agriculture, range and forest sub-sectors in Sudan. Thus, compilation of international, regional and national basic and applied research on desertification in Sudan is essential for the advancement of sustainable development of both plant and animal sectors. Basic research is an essential prerequisite for discovering practical methods for combating desertification processes and advancing biological productivity (Mustafa, 2004). The main objective of this paper is to present review of research on the various aspects of land degradation/desertification processes in Sudan. Emphasis will be laid upon wind erosion which is prevalent in Sudan; besides displaying studies and research that must be carried out to fill the gaps in the area of wind erosion.

\subsection{Estimation of desertification in Sudan}

The third edition of the World Atlas of Desertification (Cherlet et al., 2018) indicated that it is not possible to deterministically map the global extent of land degradation, and its subset - desertification, pointing out that the complexity of interactions between social, economic, and environmental systems make land degradation not amenable to mapping at a global scale. Instead, Cherlet et al., (2018) presented global maps highlighting the convergence of various pressures on land resources. Sudan was subjected to different complex disasters such as drought, desertification, famine, floods, pest infestation conflicts and war (Nour, 2007). Most of these disasters are triggered by desertification and climate change Eltoum et al., 2014. Recent researches support the evidence of presence of desert and desert like condition more to the south of the northern border of southern Sudan (FEWSENT, 2011). Desertification in Sudan was monitored in few spot areas using remote sensing and geographical information system. Stebbing, 1980, use the desert boundary to monitor the encroachment of the Sahara (desert). The desert boundary is an artificial boundary that separates the grate Sahara of Africa from the Sudano Sahelian vegetation zone (semi desert area) in Sudan. Due to anthropogenic and climate change, an annual shift was reported by many researchers, historically, (Harrison and Jackson, (1958); DECARB, (1976); Lampery, 1975; Salih, 1994; Ayoub, 1998, 1999; Ali and Bauimi, 2004; Dafalla, et al., 2007; Eltoum and Dafalla, 2014; Dregne, (1991); Mustafa, 2008) and recently Eltoum et al., 2015). The last assessment report considered as the first effort for mapping desertification in Sudan Fig. (1). The annual rate of this shift depends on the rate of change of climatic, biotic and a biotic factor. Understanding this shift is very important in monitor desertification, measure required response to prevent, mitigate and/or stop the desert creeping.

\section{Soil erosion}

Soil erosion is a natural geological process and it is impossible to stop; so the main goal is to manage human impacts on the soil reflecting in an acceptable rate of erosion. In the 2015 Status of the World's Soil Resources Report (FAO and ITPS, 2015), soil erosion was judged to be the number one threat to soil functions in five of seven regions (Africa, Asia, Latin America, Near East and North Africa, and North America); in the first four of those regions, the trend for erosion was deteriorating. Only in Europe, North America and the Southwest Pacific was the trend in erosion deemed to be improving.

The different disciplines that focus on soil erosion often use different units to report results. In soil science, the norm is to report net soil change in units of mass per area per time-most commonly as tons per hectare per year (tons $/ \mathrm{ha}^{-1} / \mathrm{yr}^{-1}$ ). By convention net soil loss is reported as a negative value, and net soil gain (through deposition) as a positive value. The rates of erosion measured in different studies are very dependent of the 
scale of the study. For example, rates measured from small experimental plots $\left(10^{-4}\right.$ to $\left.10^{2} \mathrm{~m}^{2}\right)$ will be very different from those measured on complete hill slopes or catchments $\left(10^{4}\right.$ to $\left.10^{9} \mathrm{~m}^{2}\right)$ (Garcia-Ruiz et al. , 2017).

\subsection{Wind erosion}

Wind erosion is defined by Mustafa (2007) as "the soil physical process by which dry, loose and fine surface soil particles are picked up and transported and/or moved along the soil surface by wind and thereby abrade the soil surface material by wind-born particles." This process is a two-step process,

Namely detachment of primary soil particles from the soil mass (also called deflation) happened When the wind flows over the surface of the land, a turbulent zone occurs next to the soil surface and extends into the lower atmosphere (Fryrear, 2012). This action facilitates the transfer of momentum from the wind to the soil surface and exerts a drag or shear stress on the soil surface, coinciding with wind velocity at the surface exceeds the threshold velocity (V [?] $5.4 \mathrm{~m} / \mathrm{sec}$ ) required to move the least stable soil particle When the wind velocity or energy is below the threshold value to transport soil particles, deposition occurs. Chappell et al. (2019) made global wind erosion model on threshold velocities. Soil particles move by three mechanisms according to their diameter: suspension $(\mathrm{d}<0.1 \mathrm{~mm})$ saltation $(\mathrm{d}=0.1-0.5 \mathrm{~mm})$ and surface creep $(\mathrm{d}=\mathrm{d}>$ $0.5 \mathrm{~mm}$ ). The conditions conducive to wind erosion include: loose, dry, and dispersed soil particles, smooth surface soil, lack or sparse vegetative cover, large and extensive field and erosive winds. Human-induced wind erosion is a major cause of land degradation associated with desertification (D'Odorico et al., 2013). The analysis by Ginoux et al. (2012) assigns 75 percent of global dust emissions to natural sources and 25 percent to anthropogenic or human-induced sources. The devastating wind erosion events in western North America during the 1930s led to considerable erosion research and to the establishment of agencies such as the Soil Conservation Service in the United States of America and the Prairie Farm Rehabilitation Administration in Canada, both of which were established in1935.

\subsubsection{Erosion effects on soil productivity and crop yields}

Erosion has three primary effects on crop growth and yield: removal of the fertile surface soil horizon, incorporation of denser subsoil into the surface layer, and a possible decrease in the rooting zone of the soil (Van Oost and Bakker, 2012).

\subsubsection{Erosion effects on soil organic carbon}

Surface soil layer (the A horizon) has a higher content of soil organic matter (SOM) than lower horizons. Erosion has a major effect on the storage of SOC in the landscape. The changes to SOC stores are the net outcome of a series of interacting processes associated with erosion reviewed by Doetterl et al., 2016. Chappell et al. (2019) report mean wind erosion rates for the period between 2001 and 2016 of 1.0 to 7.0 tons $/ \mathrm{ha}^{-1} / \mathrm{yr}^{-1}$ in many regions, resulting in mean SOC erosion of between 0.1 and 0.4 tons $/ \mathrm{ha}^{-1} / \mathrm{yr}^{-1}$. The authors point out that the losses of this scale greatly complicate efforts to increase SOC stores through improved management practices.

\subsubsection{Erosion effects on Agrochemical contamination}

Soil erosion contributes to pollution of waterways by nutrients and by other agrochemicals such as pesticides. This pollution leads to eutrophication of waterways and the resulting impact on aquatic life as well as direct toxicity effects on organisms (Owens et al., 2005).

Harmel et al. (2006) examined nitrogen (N) and phosphorus (P) fractions in nutrient loads from watersheds in 15 states of the United States of America and two provinces of Canada. Particulate N and P loss contributed, on average, three times as much as dissolved forms to loads, indicating the overriding effect of soil erosion and transport on $\mathrm{N}$ and $\mathrm{P}$ loads. Phosphorus is a particular concern for eutrophication. Phosphorus is strongly retained by solid phase and transported as eroded solid particles and through transport of manure and human waste (Yuan et al., 2018).

\section{Wind erosion research in Sudan}


Wind erosion in Sudan was monitored in few spot areas using remote sensing and geographical information system. Furthermore intensity wind erosion (IWE) research conducted partially in some affected states. Till now we don't have assessment and mapping report on wind erosion covered the Sudan area. Aerial photo interpretation was used to assess the extent and severity of wind erosion in a $760 \mathrm{~km}^{2}$ area south of Khartoum, between the Blue and the White Nile, Sudan. Two sets of aerial photographs, dating back to 1960 and 1990 were assembled to compile two mosaics of the area. The results of the field checks indicated very high (90\%) purity of the mapping units and that $26.4 \%$ of the total area was affected by slight, moderate or severe wind erosion. The laboratory analysis showed that sand was transported mainly in suspension. During this period either non - eroded area became eroded ( $26 \%$ of the total area) or the severity of wind erosion increased (0.24\% of the total area) (Mukhtar, 1995 and Ibrahim et al., 2003).

Rizgalla, et al. (1999) predicted the potential wind erosion (PWE) using an equation introduced by Woodruff and Siddoway (1965). The actual intensity of wind erosion (IWE) was measured using vertical and horizontal traps in three locations near El-Obeid, North Kordofan State. The measurements were made at distances of $0,30,40,80,90$, and $120 \mathrm{~m}$ from windward edge and at different periods (fortnightly). The annual PWE of the fallow and the bare surfaces at the Western Sudan Agricultural Research Project was 0.5 and 27 ton/acre, respectively. At the fallow, burnt grass and bare sites the annual PWE values were 0.5, 28 and 38 ton/acre, respectively. In the fenced and unfenced sites, the annual PWE were 0.50 and 0.75 ton/acre, respectively. The silt plus clay content in the soil drift was $15.8 \%$ less and sand content was $2.4 \%$ greater than in the virgin soil. Furthermore, wind erosion showed pronounced spatial and temporal variation (Rizgalla, 1998).

A field experiment was conducted in Goz Alhalag village, about $50 \mathrm{~km}$ south east Atbara, River Nile State, to produce broad-base data on wind erosion in two-successive seasons (August 2008 - March 2009, August 2009 - March 2010) (Abdelwahab and Mustafa 2013). The intensity of wind erosion (IWE) was measured monthly in four directions, namely North East (NE), North (N), North West (NW), and West (W) using vertical $\left(\mathrm{IWE}_{\mathrm{v}}\right)$ and horizontal soil traps $\left(\mathrm{IWE}_{\mathrm{h}}\right)$ in a bare and a lucerne-cultivated land. In the first season, $\mathrm{IWE}_{\mathrm{h}}$ in the bare land ranged from 99.9 (W) to 109.8 (NE) with a mean of 104.4 tons/ha/day and a coefficient of variation (CV) of $3.9 \%$. Furthermore, $\mathrm{IWE}_{\mathrm{h}}$ ranged from 2.1 (Nov.) to 260 tons/ha/day (Sept.) with a CV of $93.4 \%$. The variation due to direction was much lower than the monthly variation; due to the higher monthly variability of wind erosivity. The overall mean $\mathrm{IWE}_{\mathrm{h}}$ and $\mathrm{IWE}_{\mathrm{V}}$ in the first season were 2.25- and 1.90-fold those in the second season, respectively. This effect was attributed to the higher wind erosivity in the first season. In bare lands, the overall mean $\mathrm{IWE}_{\mathrm{h}}$ was 2.42- and 2.04-fold the corresponding $\mathrm{IWE}_{\mathrm{V}}$ values in the first and second seasons, respectively. This was attributed to the fact that horizontal traps measure cumulative wind erosion by saltation, surface creep and suspension, whereas vertical traps measure soil erosion by saltation only. The result may also explain the higher variation of measurements made by horizontal as compared to vertical traps. In the cultivated fields the reverse trend was found. The ratio $\mathrm{IWE}_{\mathrm{v}} / \mathrm{IWE}_{\mathrm{h}}$ of the overall mean values was 3.2 and 2.7 in the first and second seasons, respectively. This is because in addition to reducing wind erosivity, lucerne obstructed soil particles transport to the traps, more so by surface creep than saltation. The impact of lucerne cover on soil erosion was colossal. The $\mathrm{IWE}_{\mathrm{h}}$ in the bare lands were 522- and 220.5-fold that of the cultivated fields in the two successive seasons. Growing summer and winter crops with appropriate crop residue management offer good land protection against soil erosion. However this does not preclude the establishment of a shelterbelt. The establishment of Vetiver (Vetiveria zizanioides) hedgs in the experimental site reduced the seasonal variation of soil erosion by both types of traps and significantly reduced the IWE by an average of 20.9\% (Abdelwahab et al., 2015).

Abdelwahab et al., 2014 assessed wind erosion in Atbara area using remote sensing technique. Landsat Multispectral Scanner (MSS) dated 1987 and Enhanced Thematic Mapper (ETM) dated 2005 imageries were both used to assess the status and rate of wind erosion in part of the River Nile State. Remote sensing data during the period 1987-2005, showed that the total area of loose and shifting sand dunes in some areas in south east Atbara, north Atbara and south Atbara, increased by $1.3 \%, 110.1 \%$ and $34.4 \%$, respectively. Moreover the total area of irrigated tree crops decreased by about $11.6 \%$ and $8.2 \%$ in south east Atbara and north Atbara respectively. In south Atbara there is a meager increase in the area of irrigated tree crops. According to these indications, wind erosion may be described as very severe, moderate and slight in north 
Atbara, south east Atbara and south Atbara, respectively. Bare soil, dominated by clay also decreased in 2005 by about $18.9 \%, 61.8 \%$ and $82.4 \%$ for south east Atbara, north Atbara and south Atbara, respectively. Field observations showed that the dunes on the western bank of the River Nile in north Atbara are located on the edge of the great desert with dome dunes, whereas south east Atbara is covered by coppice dunes. The total area of urban areas and rural settlements increased by $116.1 \%, 47.6 \%$ and $37.8 \%$ for southeast Atbara, north Atbara and south Atbara, respectively.

Abdelwahab and Mustafa (2016a) studied the IWE in bare and lucerne-cultivated lands in Shaaldeenab village about $17 \mathrm{~km}$ south Atbara. In the first season, $\mathrm{IWE}_{\mathrm{h}}$ in the Lucerne-cultivated land ranged from 0.10 $(\mathrm{W})$ to $0.30(\mathrm{~N})$ with a mean of 0.21 tons/ha/day and a coefficient of variation $(\mathrm{CV})$ of $49.4 \%$. Furthermore, $\mathrm{IWE}_{\mathrm{h}}$ ranged from 0.12 (Sept.) to 0.40 tons/ha/day (Aug.) with a CV of $39.0 \%$. Whereas, IWE $\mathrm{V}_{\mathrm{V}}$ ranged from $0.23(\mathrm{~W})$ to $0.51(\mathrm{NW})$ with a mean of 0.39 tons/ha/day and a coefficient of variation (CV) of $30.6 \%$., Furthermore, $\mathrm{IWE}_{\mathrm{V}}$ ranged from 0.0.30 (Sept.) to 0.43 tons/ha/day (Dec. and Feb.) with a CV of $13.7 \%$. In the second season, $\mathrm{IWE}_{\mathrm{h}}$ in the Lucerne-cultivated land ranged from 0.09 (NW) to 0.27 (NE) with a mean of 0.18 tons/ha/day and a coefficient of variation $(\mathrm{CV})$ of $45.0 \%$. Furthermore, $\mathrm{IWE}_{\mathrm{h}}$ ranged from 0.12 (Jan.) to 0.37 tons/ha/day (Aug.) with a CV of $43.9 \%$. Whereas, $\mathrm{IWE}_{\mathrm{V}}$ ranged from $0.22(\mathrm{~W})$ to $0.46(\mathrm{~N}$ and NE) with a mean of 0.35 tons/ha/day and a coefficient of variation $(\mathrm{CV})$ of $37.5 \%$;. Furthermore, $\mathrm{IWE}_{\mathrm{V}}$ ranged from 0.0.25 (Dec.) to 0.42 tons/ha/day (March) with a CV of $22.1 \%$. The impact of the Lucerne cover was highly significant. The $\mathrm{IWE}_{\mathrm{h}}$ values in the bare land were 44.4 and 62.2 -fold those of the Lucerne-cultivated fields in the two successive seasons.

Abdelwahab and Mustafa (2016b) assessed the vertical and horizontal wind erosion and their interrelationships in Barber area in the River Nile State. The intensity of wind erosion was measured monthly in four directions: west $(\mathrm{W})$, northwest $(\mathrm{NW})$, north $(\mathrm{N})$ and north east (NE) using vertical (IWEv) and horizontal (IWEh) traps. In the first season (August 2008-January 2009), IWEh ranged from 183.3 (W) to 200 (NE) with a mean 192.9 ton ha $^{-1}$ day $^{-1}$ and a CV of 4.2\%. Furthermore, IWEh ranged from 123.3 (October) to 262 (August) with a mean 192.9 ton $\mathrm{ha}^{-1} \mathrm{day}^{-1}$ and a CV of $33.2 \%$, whereas, IWEv ranged from 70 (W) to 127 (NW) with a mean of 108.8 ton ha $^{-1}$ day $^{-1}$ and a CV of $24.1 \%$. Furthermore, IWEv ranged from 65.3 (September) to 156.1 (January) with a mean 108.8 ton $\mathrm{ha}^{-1}$ day $^{-1}$ and a CV of $32.2 \%$. In this season, the mean IWEh was 1.8 fold that of IWEv.

In the second season (August 2009 - January 2010), IWEh ranged from 130.5 (W) to $162.1(\mathrm{~N})$ with a mean 150.7 ton $\mathrm{ha}^{-1} \mathrm{day}^{-1}$ and a CV of 9.5\%. Furthermore, IWEh ranged from 254.5 (January) to 29.0 (December) with a mean 150.7 ton $\mathrm{ha}^{-1} \mathrm{day}^{-1}$ and a CV of 56.1\%., whereas, IWEv ranged from 96.6 (NW) to 49.5 (W) with a mean of 80.3 ton $\mathrm{ha}^{-1} \mathrm{day}^{-1}$ and a CV of $26.1 \%$. Furthermore, IWEv ranged from 151.7 (January) to 9.1 (October) with a mean 80.3 ton $\mathrm{ha}^{-1} \mathrm{day}^{-1}$ and a CV of $70.5 \%$. In this season, the mean IWEh was 1.9 fold that of IWEv. The overall mean IWEh and IWEv was 1.28 and 1.35 fold those in the second season, respectively. In both seasons the intensity of wind erosion varied with month and direction. The prevailing north winds caused high IWE in January (NNW), February (NW) and March (NW) and exhibited dust storms. In both seasons the results showed highly significant (P [?] 0.001) polynomial relationships between IWEh and IWEv.

Abuzeid et al., (2015a) studied the extent of sand movement by saltation and surface creep in three areas differing in land form, namely Al-Baja (Wadi Howar), west of Al-Golied town and Al-Khowie (south of Al-Seliem basin), using soil trenches. The computed Slianinov index was 0.005 for Wadi Halfa, 0.027 for Dongola and 0.054 for Karima. The aridity index of the three locations was $<0.05$. Thus, both indices indicate that the three locations are hyper-arid. In the first season, the rate of sand movement in all months, excepting July, in El khowie was significantly $(\mathrm{P}<0.001)$ higher than that in Al-Golied. In July the rates were equal. In this season the overall mean monthly rate at El-Kowie was $1.39 \mathrm{~m}^{3} / \mathrm{m}-\mathrm{w}$, which was more than 4-fold that in Al-Golied $\left(0.32 \mathrm{~m}^{3} / \mathrm{m}-\mathrm{w}\right)$. This was attributed to the fact that Al-Khowie is a dune field whereas west of Al-Golied is a gravely peniplain (desert pavement). In the second season, the mean monthly rate was $1.69 \mathrm{~m}^{3} / \mathrm{m}$-w in Al-Khowie, which was 3.8-fold that of Al-Golied $\left(0.44 \mathrm{~m}^{3} / \mathrm{m}-\mathrm{w}\right)$ and 5.3 -fold that of Al-Baja $\left(0.32 \mathrm{~m}^{3} / \mathrm{m}-\mathrm{w}\right)$. The lowest sand drift at Al-Baja site was attributed to the fact that Al-Baja 
land form is a sand sheet plain. The higher sand movement in the second season was due to the higher wind erosivity in that season as indicated by sand storm visibility [?] $1 \mathrm{~km}$. It is recommended to elaborate a State program as an integral part of the National Action Program for combating desertification and initiate its implementation.

Abuzeid et al,. (2015b) studied the relationships between rate, height of rise, direction and duration of measurement of sand saltation in three selected sites in the Northern State, Sudan. The rate of sand saltation at $0-30 \mathrm{~cm}\left(\mathrm{ROS}_{0-30}\right)$ and $30-60 \mathrm{~cm}\left(\mathrm{ROS}_{30-60}\right)$, and at three directions: NE, N and NW were measured at Al-Baja (Wadi Howar Inlet Fan). Furthermore, a trap with stacked chambers was used to investigate the effect of height of rise and measurement period $(28,15$ and 2 days) on ROS at Al-Baja, AlGolied, and Al-Afad. In all months at Al-Baja, with the exception of November, $\mathrm{ROS}_{0-30}$ was significantly much higher than $\mathrm{ROS}_{30-60}$. In November the wind was not erosive. The mean seasonal monthly $\mathrm{ROS}_{0-30}$ was $85.7 \%$ of that at $\mathrm{ROS}_{0-60}$. The following linear regression equation was derived from Al-Baja data:

$\operatorname{ROS}_{0-60}=1.1565 \operatorname{ROS}_{0-30}\left(r^{2}=1\right)(1)$

The monthly distribution of $\mathrm{ROS}_{0-30}$ at $\mathrm{NE}, \mathrm{N}$ and $\mathrm{NW}$ directions were qualitatively similar. However, ROS at $\mathrm{N}$ direction was 1.5 -fold that at $\mathrm{NE}$ or $\mathrm{NW}$ direction. The cumulative ROS (CROS) versus height $(\mathrm{H})$ fitted a highly significant $(\mathrm{P}<0.001)$ quadratic equation for the three locations. As an example the equation for Al-Baja was as follows:

CROS $=-0.0016 H^{2}+0.151 H+0.805\left(r^{2}=0.995, n=20\right)(2)$

CROS $(0-30 \mathrm{~cm})$ expressed as percentage of CROS $(0-60 \mathrm{~cm})$ was 78.8 in Al-Afad, 86.6 in Al-Baja; and 70.5\% in Al-Golied, indicating that CROS $(0-30 \mathrm{~cm})$ varied with location due to land form. CROS versus height at Al-Baja resulted in nearly equal CROS (0-30) regardless of period of measurement. It is recommended to use a trap with a $0-60 \mathrm{~cm}$ slit and the shortest possible period of measurement depending on land form and wind erosivity. Abuzied, 2009 found the amount of sand encroaching in to the Nile course was measured to be $0.0454 \mathrm{~m}^{3} / \mathrm{m}$-width/ day $\left(45.5 \mathrm{~m}^{3} / \mathrm{km}\right.$-width/ day).

Abuzeid et al., (2017) assessed the wind erosion in central part of the northern state during the period 19612000; data from remote sensing; aerial photographs of 1961-2000, Landsat ETM 2000, and GPS reading during field surveys 2005/2006 and 2006/2007 were the main sources of information. The results showed that two levels of wind erosion severity are present in the study area. The severe level as defined by slight to moderate rate of sand drift $\left(3-5 \mathrm{~m}^{3} / \mathrm{m}-\mathrm{w} / \mathrm{yr}\right)$ is confined to the left side of River Nile and the very severe level that has a high rate of sand drift $\left(16-17 \mathrm{~m}^{3} / \mathrm{m}-\mathrm{w} / \mathrm{yr}\right)$ is found at the right side of the River. The rate of sand dune movement was found to be in a range of $6 \mathrm{~m} / \mathrm{yr}$ for large dune to $23 \mathrm{~m} / \mathrm{yr}$ for small one. Moreover some wind erosion studies were undertaken included assessment of the intensity of wind erosion (IWE) in north east Al-Butana (Haikal, 2005) and Khartoum State (Farah, 2003).

\subsection{Wind erosivity}

Two main factors affect wind erosion: wind erosivity and soil erodibility. Wind erosivity is a measure of the ability of wind to pick the soil particles from the soil surface and transport them by saltation or push them on the soil surface (surface creep) or blow them and transport them by suspension. Soil erodibility is the susceptibility of a dry soil or its ease of detachment and transport by wind. It is a measure of the susceptibility of the soil to erosion. There are two indices of erosivity, namely the pressure of prevailing erosive winds and the index introduced by Skidmore and Woodruff in 1968 (Mustafa, 2007). Both indices are dependent on erosive wind velocity. The velocity of erosive winds depends upon the size of the particles eroded by it. Erosive winds were classified according to Beaufort scale of wind velocity and equivalent pressure at $40 \mathrm{~m}$ height. It was reported that even under gentle breeze $(3.4-5.4 \mathrm{~m} / \mathrm{sec}$.) soil particles are carried away. With a fresh breeze $(8.0-10.7 \mathrm{~m} / \mathrm{sec})$ sand is lifted into the air. In strong breeze (10.8-13.8 $\mathrm{m} / \mathrm{sec}$ ) heavy erosion sets in. Dust storms arise in a fresh gale $(17.2-20.7 \mathrm{~m} / \mathrm{sec})$. In general, turbulent wind velocity increases with height above the ground surface according to an exponential law (Mustafa, 2007).

Abdelwahab and Mustafa (2015) assessed wind erosivity of Atbara for two successive seasons (August 2008 - 
March 2009 and August 2009 - March 2010) using an equation introduced by Skidmore and Woodruff (1968). Erosive wind speeds $(\mathrm{V}>5.4 \mathrm{~m} / \mathrm{sec})$, wind direction and duration data for both seasons were used. The results showed that both hourly and monthly wind speed and erosive wind speed varied widely in magnitude and direction in both seasons. The diurnal variation was much lower than the monthly variation. In the first season, for example, erosivity ranged from 0 (Nov.) to 369.8 (Feb.) with a mean of 255.1 and CV of $43.6 \%$. The results showed that the direction of the highest contribution of erosive winds in August $(75.6 \%)$ in summer was from SW followed by that from S (10.5\%); whereas during January in winter the highest contribution was from NNW (59.4\%) and N direction (19.9\%).

\section{Research gab on wind erosion}

Due to limited financial resources for anti-desertification research, there is a real gap in combating desertification research generally, and wind erosion particularly such as:

Stabilizing soil particles by various natural or synthetic cementing and flocculating materials that increase the non- erodiable soil particles (NEP) on the soil surface; producing a rough and cloddy surface; maintaining sufficient vegetative cover; and establishing barriers or shelter belts barriers to reduce effective field length traveled by the wind. Furthermore there is a lack in studies focused on measuring sand encroaching into the Nile, winds data analysis, losses of nutrients and organic matter particularly that caused by wind erosion. Still there is urgent need to conduct researches on design and implementation of shelter belts and specify type of trees, number of rows, density and distance.

\section{Conclusions and recommendations}

Unfortunately intensity wind erosion research conducted in a part of affected states due to limited financial resources for combating desertification research. The amount of sand encroaching in to the Nile was measured to be $0.0454 \mathrm{~m}^{3} / \mathrm{m}$-width/day $\left(45.5 \mathrm{~m}^{3} / \mathrm{km}\right.$-width/ day). Fallowing and burning of a fallow land near El-Obeid reduced potential wind erosion (PWE) measured by an empirical model by 98.7 and 26.3\%, respectively, where fencing an enclosure within that fallow land reduced PWE of the fallow by $33.3 \%$. Wind erosivity exhibited very high temporal (daily, monthly and annual) and directional variation. The inevitable failure for desertification research that is not integrated with poverty alleviation programs because of the desertification caused and aggravated mainly by negative human activities, most of the affected states population are poor and rely on natural resources. It is time to fill the gap in studies and research and covers the all types of desertification processes. In scientific research institutes there is a lack of co-ordination between them leads to redundant or duplicate research and finally dissipated efforts and time.

\section{Hosted file}

3.doc..docx available at https://authorea.com/users/337854/articles/463474-review-onadvances-of-research-on-wind-erosion-and-wind-erosivity-in-sudan

\section{Hosted file}

4.doc..docx available at https://authorea.com/users/337854/articles/463474-review-onadvances-of-research-on-wind-erosion-and-wind-erosivity-in-sudan

\section{Hosted file}

5.doc..docx available at https://authorea.com/users/337854/articles/463474-review-onadvances-of-research-on-wind-erosion-and-wind-erosivity-in-sudan

\section{Hosted file}

6.doc..docx available at https://authorea.com/users/337854/articles/463474-review-onadvances-of-research-on-wind-erosion-and-wind-erosivity-in-sudan

\section{Hosted file}


7.doc.docx available at https://authorea.com/users/337854/articles/463474-review-onadvances-of-research-on-wind-erosion-and-wind-erosivity-in-sudan

\section{Hosted file}

8.doc.docx available at https://authorea.com/users/337854/articles/463474-review-onadvances-of-research-on-wind-erosion-and-wind-erosivity-in-sudan

\section{Hosted file}

9.doc..docx available at https://authorea.com/users/337854/articles/463474-review-onadvances-of-research-on-wind-erosion-and-wind-erosivity-in-sudan

\section{Hosted file}

10.doc.docx available at https://authorea.com/users/337854/articles/463474-review-onadvances-of-research-on-wind-erosion-and-wind-erosivity-in-sudan

\section{Hosted file}

11.docx available at https://authorea.com/users/337854/articles/463474-review-on-advancesof-research-on-wind-erosion-and-wind-erosivity-in-sudan

\section{Hosted file}

12.doc.docx available at https://authorea.com/users/337854/articles/463474-review-onadvances-of-research-on-wind-erosion-and-wind-erosivity-in-sudan

\section{Hosted file}

13.doc.docx available at https://authorea.com/users/337854/articles/463474-review-onadvances-of-research-on-wind-erosion-and-wind-erosivity-in-sudan

\section{Hosted file}

14.doc.docx available at https://authorea.com/users/337854/articles/463474-review-onadvances-of-research-on-wind-erosion-and-wind-erosivity-in-sudan

\section{Hosted file}

15.doc.docx available at https://authorea.com/users/337854/articles/463474-review-onadvances-of-research-on-wind-erosion-and-wind-erosivity-in-sudan 


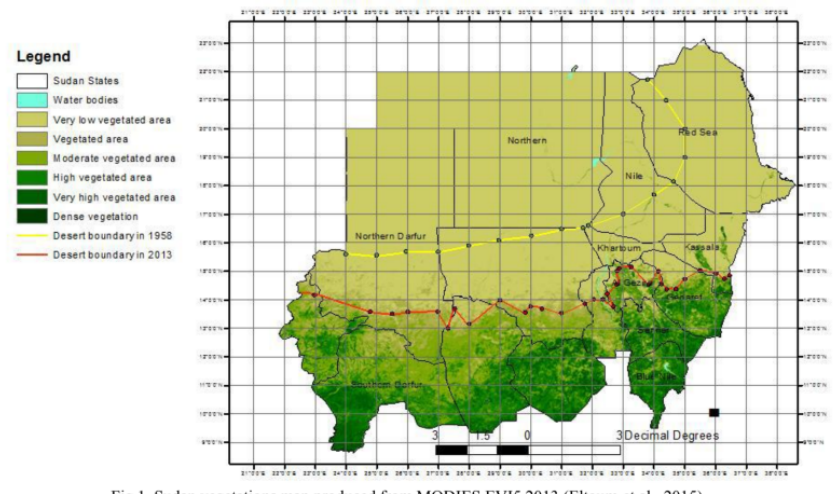

Fig.1. Sudan vegetations map produced from MODIES EVI5 2013 (Eltoum et al., 2015). 